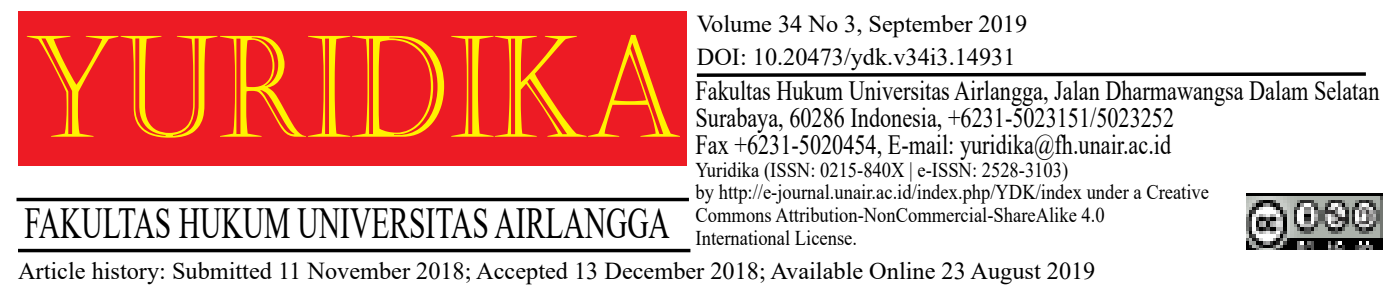

\title{
Enhancing the Environmental Impact Assessment for the Foreign Direct Investment Regime in Vietnam: an Analysis from Integration Perspective
}

\author{
Tran Viet Dung* \\ tvdung@hcmulaw.edu.vn \\ Ho Chi Minh City University
}

\begin{abstract}
Foreign direct investment (FDI) plays an important role in the economic growth of Vietnam, contributing to nearly 22 per cent of the GDP. To attract FDI the government has committed to promoting investment climate and ensuring FDI protection under various international arrangements. FDI inflows into the manufacturing and processing sectors have seen a strong increase after Vietnam's successful accession to the WTO. However, FDI also contributes to various environmental problems and challenges in Vietnam. From 2008 to 2017, most serious environmental disputes related to manufacturing activities were caused by FDI enterprises. The sanctions against FDI enterprises, however, may jeopardise the state's responsibilities under investment protection treaties. One of the few realistic approaches to strengthening the environmental management of FDI is to promote the participation of the public in the environmental risk assessment and amend the investment treaties to regulate the issue of environment management. This study will adopt an integrative approach by integrating the rules and principles of environmental management into the FDI regime of Vietnam.
\end{abstract}

Keywords: FDI; Investment; Industrial Polution; Environmental Assessment; Public Participation; EVFTA.

\section{Introduction}

The last two decades have been an extraordinary period for Vietnam. The country has undergone a dramatic economic development from a centrally planned

* Associate Professor, Dean of International Law Faculty of Ho Chi Minh City University of Law. The research reflected in this article has benefited from funding through the European Union's Horizon 2020 research and innovation programme under the Marie Skłodowska-Curie grant agreement No 734712 . 
economy to a "socialist-oriented market economy" under the umbrella of the Doi Moi (Renovation) Policy. Attracting Foreign Direct Investment (FDI) has been a key part of Vietnam's external economic affairs since the 1990s. The Government of Vietnam has made tremendous efforts to develop the business and investment climate by recognizing that the FDI sector is an integral part of the economyessential to restructuring the economy and creating a national competitiveness. ${ }^{2}$

FDI inflows have seen a steady and strong increase after Vietnam's successful accession to the World Trade Organization (WTO). The period of 2010 to 2015 showed the establishment of Vietnam as a major manufacturing hub in the region, with the large majority of FDI flowing into the manufacturing and processing sector. ${ }^{3}$ According to Vietnam's Chambers of Industry and Trade, the country attracted \$US300 billion in 2016. The FDI sector accounts for approximately 70 per cent of the Vietnam export turnover, equivalent to 22 per cent of the GDP. FDI projects have played a very important role, not only in providing investment capital, but also in stimulating export activities, as well as introducing new labour and management skills, transferring technologies, and generating job opportunities in Vietnam.

However, FDI also contributes to various environmental problems and challenges in Vietnam. It is evident that most serious environmental disputes related to manufacturing activities during the period of 2008 to 2016 were caused by FDI companies, such as the pollution in the Thi Vai River caused by Vedan Vietnam Enterprise Corporation Limited in 2008 and Formosa Steel's toxic waste water

\footnotetext{
1 Pursuant to Political Report of the Vietnamese Communist Party Central Committee at Party Congress XII, the Vietnam's "socialist-oriented market economy" is an economy operating fully and synchronously according to the rules of a market economy while ensuring the socialist orientation suitable to each period of national development. It is a modern and internationally integrated market economy which is administered by a law-ruled socialist state and led by the Communist Party of Vietnam towards the goal of a richer population and a developed, democratic, equal, and civilised country. The term was first used in the 1992 Constitution to characterise the new model of economic structure in the era of Doi Moi.

2 World Bank, 'Vietnam Development Report 2006-Business' (World Bank, 2006) <http:/ siteresources.worldbank.org/INTVIETNAM/Resources/vdr_2006_english.pdf $>$ accessed 15 October 2017.

3 DEDC, 'Vietnam Economic Overview \& Trade Analysis' (DEDC, 2016) <http://www. dedc.gov.ae/StudiesAndResearchDocument/MTR002022016VIETNAM.pdf $>$ accessed 10 February 2017.
} 
allegedly causing a massive fish death in the Ha Tinh province in April 2016.

Arguably, Vietnam still lacks an efficient environmental regulatory program and/or the enforcement capability to ensure adequate protection of the environment in the FDI projects. However, settling this problem is not a simple task. The country needs foreign capitals and technologies for its economic development and industrialisation. Therefore, postponing the FDI activities until environmental controls are in place is not the best option for the Vietnamese government. However, the international commitments on FDI protection also prevent the Vietnamese government from taking measures against foreign investors' tantamount expropriations. Accordingly, public sanctions against polluting foreign investors may be regarded as a form of indirect expropriation, which creates an obligation on the part of Vietnam (as host state) to compensate the affected foreign investors. This principle of international investment law creates a regulatory chill situation ${ }^{4}$ likely causing the government to withhold from environmental regulations.

This study will assess the above-mentioned issues in Vietnam by analysing the legal framework for FDI and environmental protection. The paper also highlights the risks that the government must take into account upon acting on environmental violations by foreign investors. It then critically analyses the practice of an environmental risk assessment system in Vietnam, in order to identify the loopholes in the system and provide possible solutions for the problems.

\section{Overview of the Vietnamese Legal Framework for FDI and Environmental Protection}

\section{Legal framework for FDI}

Since the implementation of the Doi Moi Policy, the Vietnamese Government has emphasised the significance of foreign investments as an important source for modernization of the economy and sustainable economic growth. To attract FDI,

${ }^{4}$ The 'regulatory chill' is a term used in international investment law to refer to abstinence of states from enacting regulatory standards due to some other commitments with investors. State may have to refrain from taking action against environmental violation because it would stand in direct conflict with required investor protections under a bilateral investment treaty. 
the government introduced the Foreign Investment Law (FIL) in 1987, which was regarded as the cornerstone of the 'opened door' policy for foreign capital in Vietnam. The 1992 Constitution recognised, for the first time, the development of a market economy with socialist orientation, the concept of private property, and the right of individuals to conduct business activities. It expressly acknowledges foreign-owned capital as a legitimate sector of the economy, encouraging foreign investment and guaranteeing that assets of foreign investors will not be expropriated.

The National Assembly has further modified the FIL in 1996 and 2000 to improve the conditions for FDI, including the acknowledgment of foreign investor's rights to open branches in Vietnam and assign interests to any parties in the foreign-owned enterprises. In 2005, the Law on Investment (LOI 2005) ${ }^{5}$ and Law on Enterprises ${ }^{6}$ were passed by the National Assembly to establish a common regime and unified ground for domestic and foreign investment in Vietnam, making it easier for foreign investors to invest and carry out business in the country. This legislative development on investment was influenced by the process of negotiation to access the WTO. ${ }^{7}$ The law and regulations on investment should be harmonised with the Trade Related Investment Measures Agreement (TRIM) and other relevant agreements of WTO. In 2014, the National Assembly adopted a new Law on Investment to replace the LOI 2005 (LOI 2014), ${ }^{8}$ which deems to further update and strengthen the investment protection regime in Vietnam.

In addition, Vietnam also concluded international investment treaties to guarantee protection on foreign investment. To date, it has executed 66 Bilateral Investment Treaties (BITs) and 7 Free Trade Agreements (FTA) with investment

\footnotetext{
5 Law 59/2005/QH11 on Investment, adopted on 29 November 2005.

6 Law 60/2005/QH11 on Enterprises, adopted on 29 November 2005.

7 WTO, WTO Accession Report of the Socialist Republic Vietnam, Working Party, WT/ ACC/VNM/48 (15/11/2006). The Vietnam's commitments under the WTO influence the legal framework for foreign direct investment, regarding various issues such as the limitation on foreign ownership, corporate voting rights, trading rights, distinction of foreign invested company and domestic companies.

8 Law 67/2014/QH13 on Investment, dated 23 November 2014.
} 
provisions (TIPs). ${ }^{9}$ Most recently, it concluded FTAs with a number of important partners in Asia-Pacific and Europe, including the Comprehensive and Progressive Agreement for Trans-Pacific Partnership (CP-TPP) in 2018, the EU-Vietnam FTA in 2016, and the Korea-Vietnam FTA in 2015. The investment treaties generally provide special protections for foreign investors, such as protections against discrimination, arbitrary treatment, and uncompensated expropriation, as well as guarantees for fair and equitable treatment. ${ }^{10}$ In addition, investment treaties establish specialised investor-state dispute settlement mechanisms, which allow foreign investors to sue the government directly through an international arbitration tribunal for breach of the treaty's obligation. By concluding the investment treaties, the state seeks to bind itself to international obligations to protect FDI and accepts to limit its ability to take necessary legislative and administrative actions against FDI to protect their national interests. ${ }^{11}$ This situation changed a little with the new generation of FTAs, i.e. CPTPP and EVFTA, which started to recognise the role of environmental protection and the promotion of sustainable development. Yet, the relevant provisions under those treaties are rather vague, as it is not clear if environmental protection is supposed to prevail over investor's economic interests or not.

\section{The Legal Framework for Environmental Protection}

Environmental protection in Vietnam, like most developing countries, was not the main focus of the policy makers. The government only started to pay attention to environmental issues when facing the problems caused by some FDI industrial projects in the 1990s. The Law on Environmental Protection (LOEP) first formulated the Environmental Impact Assessment (EIA) in 1993. Accordingly, LOEP stated that owner(s) of foreign invested projects or joint ventures with foreign investment capital must prepare an environmental impact report that assesses its impact on the

\footnotetext{
9 UNCTAD, 'Investment Policy Hub' (unctad) < https://investmentpolicy.unctad.org/international-investment-agreements/countries/229/viet-nam> accessed 13 October 2017.

10 Jeswald W Salacuse, The Law of Investment Treaties (2nd edn, OUP 2015).[34].

11 Karl P. Sauvant and Lisa E. Sachs, The Effect of Treaties on Foreign Direct Investment: Bilateral Investment Treaties, Double Taxation Treaties, and Investment Flows (OUP 2009).[67].
} 
environment and stipulates appropriate preventive measures for examination by the state management agency in charge of environmental protection. ${ }^{12}$ The EIA reports will serve as one of the principal grounds on which licensing authorities can approve projects. ${ }^{13}$ However, procedures for public participation as well as the requirement for the publication of the projects' environmental information were not regulated by the law. Yet, as highlighted by Doberstein, this very first national legal document of Vietnam relating to environmental protection provided the requirements for EIA and as such set the milestone for EIA in Vietnam. ${ }^{14}$

The status of public participation in EIA has been improved under the new LOEP adopted in 2005. ${ }^{15}$ The LEOP 2005 expressly regulated the public participation in EIA by providing participatory rights for citizens through various methods, such as public meetings, announcements, or interviews on environmental matters if required by the public. ${ }^{16}$ This legislation has also shown a substantial upgrade of the requirements of EIA procedures as it emphasises that comments from the People's Committees of the Commune and local residents must be included in the EIA report. ${ }^{17}$ In addition, the body responsible for reviewing the EIA report must consider any relevant requests or recommendations from organisations or individuals before making its decision. ${ }^{18}$ The LOEP 2014 has further strengthened the public participation concept in the EIA system by stating that a representative of the local community will have the right to participate in accessing the environmental protection information of the producer and conduct measures to safeguard the rights and interests of the local community under the law. ${ }^{19}$ Hence, the provision on public participation in EIA is still very generic and does not regulate a minimum standard of public participation in the procedure, thus making the implementation difficult.

\footnotetext{
${ }^{12}$ LOEP 1993, Article 18.

${ }^{13}$ LOEP1993, Article 18.

14 Doberstein Brent, 'Environmental Capacity Building in a Transitional Economy: The Emergence of EIA Capacity in Vietnam’ (2003) 21 Impact Assessment and Project Appraisal.[25].

${ }^{15}$ Law 52/2005/QH11 on Environmental Protection, adopted on 29 November 2005.

${ }^{16}$ LOEP 2005, Article 105.

172005 Law, Article 20.

${ }_{18}$ LOEP 2005, Article 21.

19 LOEP 2014, Article 146.
} 


\section{Assessing EIA Practices in FDI Projects}

The implementation of EIA in Vietnam during the last two decades is still limited. Often the actual examination commences only when the major project decisions (including site, design, and construction preparation) already have been made, thereby rendering the EIA a mere formality. The government authorities have viewed EIA as an exercise in rationalizing predetermined outcomes, rather than a means for providing independent and rigorous analysis upon which sound decisions could be based. Many observers have attributed these problems to a lack of political will reflected in asymmetries in institutional power. ${ }^{20}$ The authority assessing the EIAs is frequently under financial pressure or politically inferior to other government institution or private proponents of the project. Furthermore, EIAs are often regarded by key decision makers at various levels of the government as a disincentive to potential investors. A general preoccupation with economic performance frequently leads to a trading-off of short-term economic benefits for longer-term environmental problems. As a consequence, this underestimation of the role and impact of EIA leads to various environmental issues caused by foreign invested companies.

Vietnam has shown efforts to develop a comprehensive and updated national legal framework on FDI and environmental protection. The LOI 2016 specifically stipulates that the state encourages and creates favourable conditions for the investors to implement investment activities that are environmental friendly and help improve a sustainable economic development. ${ }^{21}$ In the area of environmental protection, the flexibility and low standard of environmental protection of the LOEP seems to help the foreign investors to save on business performance expenses. It should be noted that in most cases the investors want to optimise production costs by extending the lifecycle of the technology, which has been banned in the MNC's

${ }^{20}$ Bruch Carl, [et.,al] 'Assessing the Assessments: Improving Methodologies for Impact Assessment in Trans Boundary Watercourses' (2007) 23 International Journal of Water Resources Development.[391].; Tan Alan Khee-Jin, 'Environmental Laws and Institutions in Southeast Asia: A Review of Recent Developments' (2004) 1 Singapore Yearbook of International Law.[177].

${ }^{21}$ LOEP 2016, Article 5.4. 
home country but is still acceptable in developing countries such as Vietnam. Many believe that the loosely designed legal regulations on environment assessment and the inefficient environmental enforcement systems in Vietnam are one of the decisive factors for attracting foreign investment. ${ }^{22}$ According to Dinh Duc Truong, nearly 20 per cent of the FDI corporates report that they can save up to ten per cent on environment protection costs in comparison to their home countries, 68 per cent admit that they can save between 10 and 50 per cent, and twelve per cent of them believe that the costs could be reduced to more than 50 per cent. ${ }^{23}$ Moreover, with low environment protection costs, taxes, and fees, 68 per cent of FDI companies expect to save between 10 and 50 per cent in their costs while operating in Vietnam, an ideal situation the investors hope to obtain once their investment projects are launched. ${ }^{24}$ With such an approach, the policy makers try to define Vietnam as an "apple of the investor's eye".

However, such a FDI favour-oriented approach in the legal framework also produces side effects related to the compliance of foreign investors to their environment protection duties. It is reported that more than 51 per cent of the investors participating in the research of Dinh Duc Truong during the period of 2012 to 2015 , admitted that their projects do not fully observe the environment protection requirements and the operation of the factory may have a negative impact on the environment. ${ }^{25}$ The reports of the Environmental Inspectorate Department of the Ministry of Natural Resource and Environment (MONRE) also showed that from 2010 to 2015, there were 89 cases where FDI companies were charged with monetary fines for violating procedural and environment standard rules. It is also observed that administrative fines are relatively low and not substantial enough to

${ }^{22}$ Dinh Duc Truong, 'Quản Lý Môi Trường Tại Các Doanh Nghiệp đầu Tư Nước Ngoài (FDI) Tại Việt Nam [Managing Environment Issues at the Foreign Invested Enterprises in Vietnam]' (2015) 31 VNU Journal of Science.[23].
${ }^{23}$ ibid. [48].
${ }^{24}$ ibid.
${ }_{25}$ ibid. 
urge strict compliance by the MNCs. ${ }^{26}$ Such non-compliance and lax regulations are the source of negative environmental impacts and potential environmental disputes. As one of the many undesired consequences of FDI, the ones who suffer most are the people living in such polluted areas, especially when they are subject to environmental disputes where their legal rights and interests are not effectively protected due to a poorly developed private enforcement mechanism-the local courts are often incompetent to settle environmental matters. For this reason, it is crucial that the public, or more particularly the people who are directly suffering from the effect of FDI projects, get their voice heard by the government. Their involvement should be promoted in all of the stages of the EIA process to balance the scale between FDI and environmental protection.

Another major constraint for public participation in Vietnam is the limited access of civil society groups in environmental governance. While in the Western countries, NGOs have become a common critical opponent to major development projects ${ }^{27}$ also reflected in the Aarhus Convention-in Vietnam, the participation of NGOs and civil society groups in the decision-making process of environmental protection is rather limited. The operation of the NGOs are generally still restricted due to the fragmentation of the legal framework for the formation and operation of NGOs and the strict control by the state. This limits the efficiency of NGOs in environmental management. Some even view the current function of NGOs in the environmental sector as similar to "state-led civil society", as they often act as a mediator between the government and its citizens but are not fully independent

${ }_{26}$ Currently the administrative fine would range from 5,000,000 VND (approximately US\$240) to $180,000,000$ VND (appromiximately US\$8,570) only. See Decree 179/2013/NĐ-CP of the Government on the Penalties for Administrative Violations Against Regulations on Environmental Protection, dated 14 November 2013 (Decree 179), sec. 2. In Singapore, according to the Environmental Public Health Act 1987 latest amended by Act 16 of 2016, the offender shall be responsible for a penalty up to 20,000 SGD (approximately US\$15,300), yet taken into account the additional fine for a continuing offence. In Thailand, pursuant to the 1992 Enhancement and Conservation of National Environmental Quality Act, B.E. 2535, the penalty for failure to meet environmental standards is to one-year imprisonment and a fine of up to 100,000 bahts (around US\$3,500).

${ }^{27}$ Benedict Kerkvliet, Authorities and the Peoples: An Analysis of State-Society Relations in Vietnam (Post-war V, Rowan and Littlefield 2003).[27]. 
of the state. ${ }^{28}$ Hence, it is argued that independent NGOs and other civil society groups could contribute greatly to the information collection, dissemination, and assessment, while monitoring the environmental impacts of projects and providing advocacy for environmental justice. In fact, the role of NGOs and civil society groups in official intergovernmental processes on the environment are acknowledged in Agenda 21, the comprehensive sustainable development blueprint adopted at the 1992 Rio Earth Summit.

\section{Formosa Case}

The drawbacks of EIA in Vietnam can be illustrated by a typical infamous pollution dispute at Formosa Ha Tinh steel plant in 2016, which seriously affected the marine life of the four sea coastal provinces of Ha Tinh, Quang Binh, Quang Tri, and Thua Thien-Hue in central Vietnam. This case reflects the present issue with the practical application of public participation in EIA concerning a big but environmental sensitive FDI project.

In 2016, the Formosa illegally discharged toxic industrial waste into the ocean through drainage pipes. Fish carcasses were reported to have washed up on the beaches of Ha Tinh province starting 6 April 2016.29 Later, a large number of dead fish were found on the coast of Ha Tinh as well as three other provinces Quang Binh, Quang Tri and Thua Thien-Hue until 18 April 2016.30 The local authorities estimated that seafood catches fell 1,600 tons per month; 140 tons of fish, 67 tons of oysters and 16 tons of shrimp died as a result of the disaster. The toxic pollution caused by Formosa hit at least 200,000 people, disrupting their lives and destroying

\footnotetext{
${ }^{28}$ Lux Steven and Jeffrey Straussman, 'Searching for Balance: Vietnamese NGOs Operating in a State-Led Civil Society' (2004) 24 Public Administration and Development.[173].

${ }_{29}$ Reuters, 'Vietnam, Grappling with Mass Fish Deaths, Clamps down on Seafood Sales' (Reuters, 2017) <http://www.reuters.com/article/us-vietnam-formosa-plastics-environment/vietnam-grappling-with-mass-fish-deaths-clamps-down-on-seafood-sales-idUSKCN0XP0QD $>$ accessed 10 October 2017.

${ }^{30}$ Diep Pham and Mai Ngoc Chau, 'Beaches of Dead Fish Test New Vietnam Government's Response' (Bloomberg, 2016) <https:/www.bloomberg.com/news/articles/2016-05-01/beachesfull-of-dead-fish-test-new-vietnam-government-s-response $>$ accessed 10 October 2017.[32].
} 
their livelihoods. ${ }^{31}$ The Formosa case is considered the biggest and most serious environmental pollution incident in Vietnam. ${ }^{32}$

On 30 June 2016, after facing the unrested wave of anger from the locals and pressure from the media for two months, Formosa reached a settlement agreement with the government stating that Formosa would pay VND 11.5 trillion (around US\$500 million) in compensation to treat the pollution and mitigate consequences. ${ }^{33}$ However, many affected people were still unhappy with the result of the settlement agreement, as they wanted Formosa to pay for more compensation, do a better environmental clean up and close the steel plant to avoid potential similar environmental disasters in the future. Many blamed the government of ineffective negotiation. The government in fact had to face a dilemma while representing the interests of the victims, namely how to mitigate the state's own responsibilities of investment protection against Formosa, as the government had approved the EIA of the project and the investors had invested into the project. Improper actions of the government can lead to serious legal consequences as foreign investors are well protected under the international investment law. ${ }^{34}$ The settlement agreement with Formosa, therefore, could be seen as the most appropriate solution that could be accepted by investors without leading to the termination of the project.

The Formosa shows a typical problem of the current investment regime in Vietnam. The FDI project of Formosa was expected to be a large dynamic project that would motivate other industrial projects and sectors, thus contributing to the rapid economic restructuring to help Ha Tinh-one of the poorest provinces of

${ }^{31}$ MONRE, 'Report on the Environmental Issues at FDI Projects Period 2015-2017 (Báo Các Đánh Giá Vấn Đề Môi Trường Tại Các Dự Án Có Vốn Đầu Tư Nước Ngoài)’ (2017).

${ }^{32}$ Huong Dieu, 'Prime Minister Nguyen Xuan Phuc: To Close the Steel Plant If Formosa Violates Again [Thủ Tướng Nguyễn Xuân Phúc: Nếu Formosa vi Phạm Trở Lại Sẽ Đóng Cửa Nhà Máy]' (baomoi, 2017) <http://www.baomoi.com/thu-tuong-nguyen-xuan-phuc-neu-formosa-vipham-tro-lai-se-dong-cua-nha-may/c/22834093.epi> accessed 10 October 2017.

33 Ngoc Lan, 'Formosa Agrees to Compensate US\$500 Million for Mass Fish Deaths' (Saigon Times online, 2016) < http://english.thesaigontimes.vn/48314/Formosa-agrees-to-compensateUS\$500-million-for-mass-fish-deaths.html> accessed 10 October 2017.

${ }^{34}$ Tran Viet Dung, 'Expropriation of Foreign Investors Assets upon Environmental Violation [Truất Hữu Tài Sản Của Nhà Đầu Tư Nước Ngoài Trong Trường Hợp Làm ô Nhiễm Môi Trường]' (2016) 99 Journal of Legal Science.[12]. 
Vietnam-to become industrialised in the near future. However, after some years of operation, Formosa started to cause serious environmental pollution, affecting the development of the economy and creating political instability for the locals. One of the main reasons for the problems around Formosa is that the EIA was not effectively implemented, as a number of loopholes could be found in the EIA proceeding to the Formosa project.

Firstly, there was a lack of independent transparency in the appraisal of environmental impact assessment reports of the Formosa project. According to the official record, the EIA report of the Formosa project was prepared by an assessment team comprising of three members of the investor, three members from the Hanoi University of Technology, and three members from the Centre for Consultancy, Training and Transfers Environmental Technology under the Vietnam Environmental Administration Department (VEA). Meanwhile, the appraisal body approving the EIA report was the Department of Environmental Impact Assessment under the VEA. It is assumed that such assessment procedure could hardly be objective and independent.

In fact, the EIA report of the Formosa project is 285 pages long, divided in nine chapters, designed in accordance with the guidelines on EIA report of Circular 08/2006/TT-BTNMT of the MONRE. ${ }^{35}$ However, most of the content of the report focuses on describing the socio-economic impact of the project; the part relating to the analysis of the environmental impacts of the project and a forecast of the risks of environmental incidents were sketchy. The assessment of environmental impact of wastewater in the steel plant operation is less than three pages-of which about one and a half page merely contain tables-and mainly list the category of waste water of the plant without giving any information on how such wastewater could affect the environment. The session on prevention and response to environmental

\footnotetext{
${ }^{35}$ Circular 08/2006/TT-BTNMT of MONRE Guiding the strategic environment assessment, environmental impact assessment and environmental protection.
} 
incidents is extremely general and vague. ${ }^{36}$ Despite the above mentioned, the assessment team still supported the EIA report without raising any questions or clarifications concerning Formosa. It is observed that the environmental authorities are pressured not to prevent FDI projects that could create jobs, increase revenue, and most importantly, the industrialization process in the locality. Thus, to ensure the effective EIA system, it is important to establish truly independent and transparent mechanisms for assessment.

Secondly, the consultation with the local community on the EIA report was conducted in a cursory manner. The EIA report was merely sent to the People's Committee and Fatherland Front Committee of Thanh Lac Commune to collect written comments. However, it is well known that members of the People's Committee and Fatherland Front Committee of the communes do not possess the technical knowledge for this nor do they have an adequate understanding of the environmental impact of the subject matter. They therefore responded positively to the EIA report, expressing their support for the project of Formosa and only noting that investors must apply necessary measures to reduce the adverse environmental impact.

According to Table 8.1 of the EIA report, a community consultation session was conducted during the EIA: a survey of representatives of 50 local households. However, none of 298 households, who were forced to relocate due to the Formosa project, were at all involved in that EIA survey. Furthermore, according to an independent investigation of Thanh Nien News Paper, thousands of households in the locality [of the Formosa steel plant] did not take part in the EIA consultation. Tran Dinh Thanh, Secretary of the Party Committee of Ky Phuoc Commune, confirmed that when Formosa deployed the project, almost 1,000 hectares of land were acquired containing 1,500 households. ${ }^{37}$ Consequently, a

\footnotetext{
${ }^{36}$ Nguyen Hoai, 'Environmental Impact Assessment Was Sketchy, What Did The Approver Say? (Đánh Giá Tác Động Môi Trường Formosa Sơ Sài, Người Phê Duyệt Nói Gì?)’ Tien Phong Newspaper (20 July 2016) <https://www.tienphong.vn/xa-hoi/danh-gia-tac-dong-moi-truong-formosa-so-sai-nguoi-phe-duyet-noi-gi-1029391.tpo>.

37 Hue Minh, 'Formosa Has "overtaken" Peoples [Formosa "qua Mặt" Người dâN]' Thanh Niên Newspaper (26 April 2016) <https://thanhnien.vn/viet-nam/formosa-qua-mat-nguoidan-696022.html>.
} 
proper public consultation with the local community per se was totally neglected in the Formosa's EIA procedure.

Moreover, it should be noted that public participation in the EIA should not just be limited to a consultation with the local community. Public consultation in the form of open forums must be conducted to secure opinions from affected organizations, experts, and the public. Public inputs from different sources must be appended to a project's final EIA report when submitted for examination and approval. It is believed that the LOEP and its implementing regulations must further clarify two issues, namely (i) the concept of people being directly affected by the proposed project and (ii) the minimum percentage of affected people participating in EIA consultations. Currently, only people who live in the area affected directly by the project are considered as stakeholders in the environmental impact assessment procedure,38 while other interested parties, who might have an interest in the environmental conditions of the area, may not be allowed to take part in the public consultancy of the EIA procedure because they do not meet the criteria of living in the area of the project. Current laws and regulations exclude the participation of experts, who have knowledge and expertise in the subject matter, from the public consultation on environmental impacts assessment. Meanwhile, people living in the area may not be qualified and able to understand the issue and protect their rights against the development project. Based on the concept of public participation, the scope of people participating in the assessment and consultation should not be limited by their physical place of residence but rather by their interest towards environmental protection in any region of the country.

The legal system should provide mechanisms for its citizens to access information and participate in environmental protection, in particular for EIA consultations if they are directly affected by the pollution. This will create chances for scientists, intellectuals, and anyone interested in environmental issues to

\footnotetext{
38 Article 12.4, Decree $18 / 2015 / \mathrm{ND}-\mathrm{CP}$ of the Government on environmental protection planning, strategic environmental assessment, environmental impact assessment and environmental protection plan. (Decree 18/2015/ND-CP)
} 
participate in environmental protection in a more open and effective way. Meaningful participation and consultation in the evaluation of project planning, feasibility study, design, and implementation is an important requirement to safeguard the environment and can directly reflect the public's perceptions of environmental quality in the project's area of influence.

Thirdly, the time period for the competent authorities to examine the EIA report is rather short to ensure a comprehensive and deep assessment. The communelevel People's Committees of the localities where the projects are implemented and that can be directly affected by the project, have to reply in writing within only 15 working days from the date of receipt of the written project. In case of approval of the project implementation a written response is not needed. ${ }^{39}$ This provision accidentally creates a psychological hurry and pushes the authorities to approve the project. These conditions can be explained by Vietnam's eagerness for foreign investment; as such this regulation mainly aims for the creation of favourable conditions for investors, while hindering them as little as possible in the development. However, it is believed that the time period of 15 days is not long enough for members of commune-level People's Committee to read, analyse, and check the reality of the report, especially in the case of a big and complex project like Formosa. The current regulations place a heavy burden on communelevel People's Committees, without facilitating the necessary conditions to carry out consultations in terms of time, funding, human, and material resources.

Fourthly, there is a serious lack of awareness of environmental protection and of the right to access information among the local people. A survey conducted by the VEA in 2010 found that 96 per cent of the people in the village, where the industrial parks are located, were unaware of environmental impact information. The survey also reflects the issue that people have little interest in, and understanding of, their rights to request and access environmental information, leading to a low number of requests to receive environmental information. People are ignorant of their own rights to protect the

${ }^{39}$ Decree No. 18/2015/ ND-CP, Article 12.5(b). 
environment. Due to this limited legal knowledge, they are unaware of the EIA process and do not know how to approach the state agencies for information. As a result, they do not take an active part in the assessment of the environmental impact of projects.

In addition to the above shortcomings, it is assumed that almost all people would have difficulty reading technical reports, environmental specialties, including many terminologies, units of measurement, and strange and difficult metrics. In the Formosa case, the people in the locality of the Formosa project are generally poor with low education. They barely pay any attention to the environment. Thus even if they were directly involved in the survey, they would not know the essence of the EIA. It is therefore necessary to further improve people's awareness and knowledge about environmental issues, the impact of environmental pollution on their lives, and their rights to environmental protection. To that end, it is assumed that participation of NGOs and other civil society groups (having knowledge and expertise of environment and environmental law) in the EIA is of high importance. They might help educate local people about the economical and environmental impacts of investment projects in the area, and teach them their right to protect their legitimate interests.

The Formosa case is an important lesson in regards to sustainable development for Vietnam. Attracting foreign investment and creating favourable conditions for foreign businesses to invest in Vietnam is essential to boost the economy of the region in line with the government's development plan. However, the infusion of FDI capital and increased exploration and development have coincided with an increase in environmental consequences. Pollution at Formosa spread along the coastal areas of Central Vietnam and severely affected the environment, marine life, and fisheries. Postponing the FDI project and development until environmental controls are in place, however, is not a practical option. The creation and implementation of competent environmental regulatory programs would take years and desperately delay the needed revenue for the province. Moreover, the government must also observe the international commitments in regard to foreign investment protection. ${ }^{40}$

\footnotetext{
40 Taiwan - Viet Nam BIT (1993), Article 9.
} 


\section{Suggestions for the Improvement of the FDI Regime and Environmental Management}

The best solution for Vietnam to manage and control future environmental disasters like Formosa is to strengthen the pre-investment registration process. Besides broadening the scope of stakeholders of the EIA and promoting public participation, it is also imperative to impose a liability on foreign investors when violating the environmental regulations. The responsibility of foreign investors at the EIA must not only be limited to addressing the public concern, but they should also be fully liable for the consequences to the environment, including compensating the actual and future damages caused to the local community and helping restore the environment.

It is suggested that for big scale industrial projects, the law should request foreign investors and the government to conclude a project agreement to ensure the investment project serves both economic development and environmental protection. Environmental regulatory and compliance provisions should be incorporated into such an agreement. In this way, if the foreign investors and/or their project company violate relevant environmental protection regulations, the government would have a contract remedy that it can pursue through the local courts, or the international justice system, or arbitration.

The project agreements would hold multi-national companies (MNC) liable for any breach of contract, especially the environmental regulations, and simplify the enforcement process. The parties could address specific environmental concerns regarding the potential liability for existing or future damages and resolve them prior to the commencement of the project. Serious commitments on corporate social responsibility would help a MNC to develop its reputation and attract investors for its business operation. According to some practitioners, environmental contractual partnerships are the solution to the environmental consequences of industrialization. ${ }^{41}$

\footnotetext{
${ }^{41}$ Madeline Cohen, 'A New Menu for the Hard Rock Cafe: International Mining Ventures and Environmental Cooperation in Developing Countries' (1996) 15 Stanford Environmental Law Journal.[130].
} 
It is also critical for the Vietnamese government to amend the international obligations regarding FDI protection in case of environmental violation. Under the traditional investment treaties the rule against uncompensated expropriation has been construed in such a way as to blur the distinction between environmental regulation and indirect expropriation. Accordingly, host states are typically required, under the investment treaties, to compensate investors merely because of environmental regulation, a trend that appears to reverse "the polluter pays principle" of the environmental law.

In consequence, Vietnam must be firm in this issue as protecting the environment has become a world-accepted norm, evidenced by the negotiation of the EU-Vietnam FTA (EVFTA). The parties agreed that the FTA will aim to promote high-quality investment between Vietnam and the EU, thus replacing all existing BITs between Vietnam and EU members. It is observed that the EVFTA strikes a better balance between protecting FDI interest and protecting sustainable development. The EVFTA advocates the governments' right to pursue policies in the public interest, including protection of public health and environment. Article two of the chapter on Trade and Development of the EFVTA specifically permits the parties to establish their own levels of domestic protection in environmental and social areas, as they deem appropriate, and to adopt or modify its relevant laws and policies accordingly, consistently with the principles of internationally recognised standards or agreements. Under the EVFTA, Vietnam is permitted to implement its laws and practices in accordance with the multilateral environmental agreements (MEAs) of which it is a party. ${ }^{42}$ Modifying the international obligations under investment treaties in favour of the protection of environment will support Vietnam's efforts to grow and develop its economy sustainably in the interest of its people.

In conclusion, to improve the environmental management structures in Vietnam it is of high importance for policy makers to fully realise the role of environmental impact assessment process. An approach where the public has the

\footnotetext{
${ }^{42}$ EVFTA, Chapter Trade and Sustainable Development, Article 4.
} 
right to access to information, to contribute information and to challenge decisions would be beneficial. Successful EIA should involve the public during the early phase of investment registration in order to avoid local opposition, to gain people's confidence and reduce conflicts through the early identification of related issues. It is also equally important to tie foreign investors with social responsibilities in relation to environmental protection. The government should re-negotiate to amend the state's rights and obligations under the investment treaties in regard to environmental management issues. It is important to reduce the pressure for the government agencies in performing the country's international commitments.

\section{Bibliography}

Benedict Kerkvliet, Authorities and the Peoples: An Analysis of State-Society Relations in Vietnam (Post-war V, Rowan and Littlefield 2003).

Bruch Carl, 'Assessing the Assessments: Improving Methodologies for Impact Assessment in Trans Boundary Watercourses' (2007) 23 International Journal of Water Resources Development.

DEDC, 'VietnamEconomic Overview \& TradeAnalysis' $(D E D C, 2016)<\mathrm{http}: / / \mathrm{www}$. dedc.gov.ae/StudiesAndResearchDocument/MTR002022016VIETNAM. pdf $>$ accessed 10 February 2017.

Diep Pham and Mai Ngoc Chau, 'Beaches of Dead Fish Test New Vietnam Government's Response' (Bloomberg, 2016) < https://www.bloomberg. com/news/articles/2016-05-01/beaches-full-of-dead-fish-test-new-vietnamgovernment-s-response> accessed 10 October 2017.

Dinh Duc Truong, 'Quản Lý Môi Trường Tại Các Doanh Nghiệp đầu Tư Nước Ngoài (FDI) Tại Việt Nam [Managing Environment Issues at the Foreign Invested Enterprises in Vietnam]' (2015) 31 VNU Journal of Science.

Doberstein Brent, 'Environmental Capacity Building in a Transitional Economy: The Emergence of EIA Capacity in Vietnam' (2003) 21 Impact Assessment and Project Appraisal.

Hue Minh, 'Formosa Has “overtaken" Peoples [Formosa "qua Mặt” Người dâN]' Thanh Niên Newspaper (26 April 2016) <https://thanhnien.vn/viet-nam/ formosa-qua-mat-nguoi-dan-696022.html $>$. 
Huong Dieu, 'Prime Minister Nguyen Xuan Phuc: To Close the Steel Plant If Formosa Violates Again [Thủ Tướng Nguyễn Xuân Phúc: Nếu Formosa vi Phạm Trở Lại Sẽ Đóng Cửa Nhà Máy]' (baomoi, 2017) <http://www.baomoi. com/thu-tuong-nguyen-xuan-phuc-neu-formosa-vi-pham-tro-lai-se-dongcua-nha-may/c/22834093.epi> accessed 10 October 2017.

Jeswald W Salacuse, The Law of Investment Treaties (2nd edn, OUP 2015).

Karl P. Sauvant and Lisa E. Sachs, The Effect of Treaties on Foreign Direct Investment: Bilateral Investment Treaties, Double Taxation Treaties, and Investment Flows (OUP 2009).

Lux Steven and Jeffrey Straussman, 'Searching for Balance: Vietnamese NGOs Operating in a State-Led Civil Society' (2004) 24 Public Administration and Development.

Madeline Cohen, 'A New Menu for the Hard Rock Cafe: International Mining Ventures and Environmental Cooperation in Developing Countries' (1996) 15 Stanford Environmental Law Journal.

MONRE, 'Report on the Environmental Issues at FDI Projects Period 2015-2017 (Báo Các Đánh Giá Vấn Đề Môi Trường Tại Các Dự Án Có Vốn Đầu Tư Nước Ngoài)' (2017).

Ngoc Lan, 'Formosa Agrees to Compensate US\$500 Million for Mass Fish Deaths' (Saigon Times online, 2016) <http://english.thesaigontimes.vn/48314/ Formosa-agrees-to-compensate-US\$500-million-for-mass-fish-deaths.html> accessed 10 October 2017.

Nguyen Hoai, 'Environmental Impact Assessment Was Sketchy, What Did The Approver Say? (Đánh Giá Tác Động Môi Trường Formosa Sơ Sài, Người Phê Duyệt Nói Gì?)' Tien Phong Newspaper (20 July 2016) <https://www. tienphong.vn/xa-hoi/danh-gia-tac-dong-moi-truong-formosa-so-sai-nguoiphe-duyet-noi-gi-1029391.tpo>.

Reuters, 'Vietnam, Grappling with Mass Fish Deaths, Clamps down on Seafood Sales' (Reuters, 2017) <http://www.reuters.com/article/us-vietnam-formosaplastics-environment/vietnam-grappling-with-mass-fish-deaths-clampsdown-on-seafood-sales-idUSKCNOXP0QD> accessed 10 October 2017.

Tan Alan Khee-Jin, 'Environmental Laws and Institutions in Southeast Asia: A Review of Recent Developments' (2004) 1 Singapore Yearbook of International Law.

Tran Viet Dung, 'Expropriation of Foreign Investors Assets upon Environmental 
Violation [Truất Hữu Tài Sản Của Nhà Đầu Tư Nước Ngoài Trong Trường Hợp Làm ô Nhiễm Môi Trường]' (2016) 99 Journal of Legal Science.

UNCTAD, 'Investment Policy Hub' (unctad) < https://investmentpolicy.unctad.org/ international-investment-agreements/countries/229/viet-nam $>$ accessed 13 October 2017.

World Bank, 'Vietnam Development Report 2006-Business' (World Bank, 2006) $<$ http:/siteresources.worldbank.org/INTVIETNAM/Resources/vdr_2006_ english.pdf $>$ accessed 15 October 2017.

HOW TO CITE: Tran Viet Dung, 'Enhancing the Environmental Impact Assessment for the Foreign Direct Investment Regime in Vietnam: an Analysis from Integration Perspective' (2019) 34 Yuridika. 
--This page is intentionally left blank-- 